\title{
Gideon Biger
}

\section{International boundaries and the change of landscape The Israel-Egypt boundary as a case study}

International boundaries, their history, location, disputes concerning their exact delimitation, their strategically importance, and other facts led many scholars to deal with that important subject. International lawyers, geographers, historians, political scientists, researchers of international relations, cartographers, military people, all are concerned with the location of a boundary, its legal status, its history, its defensible ability and so on. However, the influence of the international boundaries upon the landscape where they run has not received the attention to its merits. This article will present some areas of this kind, where a political boundary brought changes to the landscape on both sides of it. The boundary between Israel and Egypt will be the case study, although some other areas will be presented.

Key words: international boundaries, natural landscape, political systems, changing of landscape.

\section{Introduction}

International boundaries are man - made separation lines (Prescott 1978), which divide more than 200 different states which exist today all over our globs (Biger 1995). These boundaries were described, a hundred years ago by Lord Curzon of Kedleston, later the British foreign secretary, as 'the razor's edge on which hangs suspended the modern issues of war and peace, or life or death to nations' (Curzon 1907). All of today's boundaries were created in the past; sometimes some years ago, sometimes some decades ago and some boundaries like the boundary between France and Spain established in 1659 or the MexicanUSA boundary established in 1853 (Roberts 2001) were even established some hundred years ago. Thus international boundaries reflect the historical moments in the life of a state, when its limits were made according to its force and ability at that time. By this, today's boundaries are relicts from the past, which make them a target for historical geography research. International boundaries, their history, location, disputes concerning their exact delimitation, their strategical importance, and other facts led many scholars to deal with that important subject. International lawyers, geographers, historians, political scientists, researchers of international relations, cartographers, military people, all are concerned 
with the location of a boundary, its legal status, its history, its defensible ability and so on (Schofield et al. 2002). The historical geographers, who are combining in their research area studies with knowledge of the past, can, and have to have their place in the scholarly world of boundary research.

Of the many criteria for establishing a boundary line the ethnic criteria are those applied most often in modern time, while in the further past, prominent physical features in the landscape were more important. Ethnic boundaries were created in order to separate culturally uniformed peoples so that a minimum of stress would be placed on them. As located at the interfaces between adjacent state territories, international boundaries have special significance in determining the limit of sovereign authority and defending the spatial form of the contained political regions (Muir 1975, p. 119). Thus political geography is rich in morphological, empirical and generic boundary studies, the influence of the international boundaries upon the landscape where they run has not received the attention to its merits. The actual function of boundaries, their most important characteristic, is their role as constant barriers. If barriers are studied only in their static distribution, then the whole character of the barrier may be easily misinterpreted or distorted. Although some scholars refer to the fact that boundaries act as barriers to social and economic processes which would otherwise transgress them without interference, not much research dealt with the difference of landscape which sometimes developed on both sides of a boundary, especially in the natural landscape. This article will present some areas of this kind, where a political boundary brought changes to the landscape on both sides of it. The boundary between Israel and Egypt will be the case study, although some other areas will be presented.

\section{Different landscape along international boundaries}

The most prominent difference between two sides of a boundary was, in the past, the area on both sides of East and West Germany, between 1945 and 1989. After the Second World War, Germany was divided between the Soviet Union on one side (later became East Germany) and the United States, Britain and France (later became West Germany) on the other side. On the East German side of the boundary there were depopulated zones, minefields, barber-wire entanglements and numerous large military bases, while people living within the more general area of the boundary were carefully vetted for reliability. The urban landscape of East Berlin was the typical East European, communist landscape of large blocks of residential apartments, all with the same style. On the West side there were areas with series of settlements which have experienced economic development based on the capitalist way of life. 


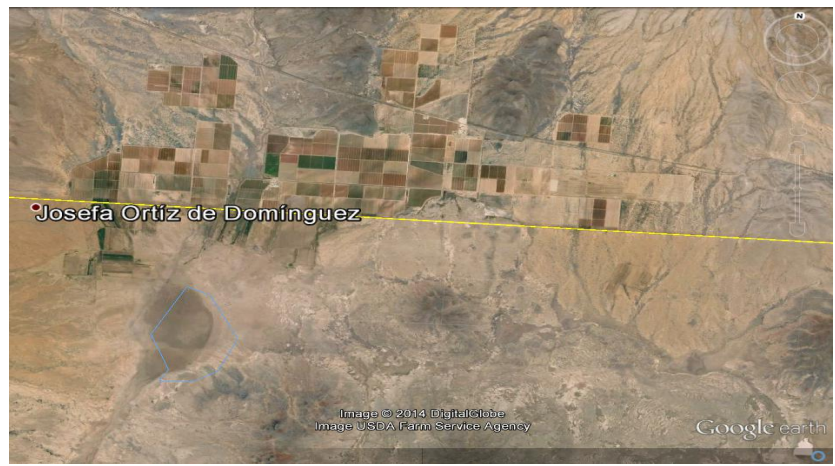

Fig. 1. USA (up) - Mexico (down) boundary

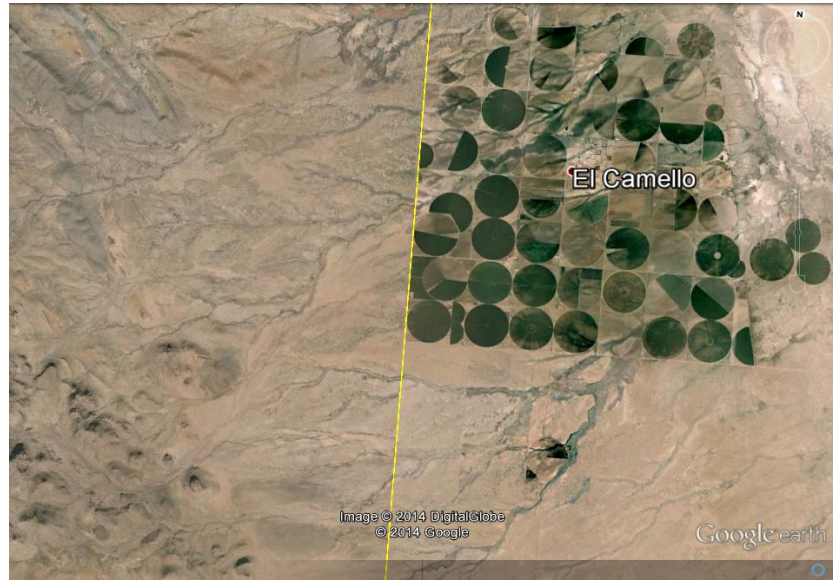

Fig. 2. Mexico (right) - USA (left) boundary

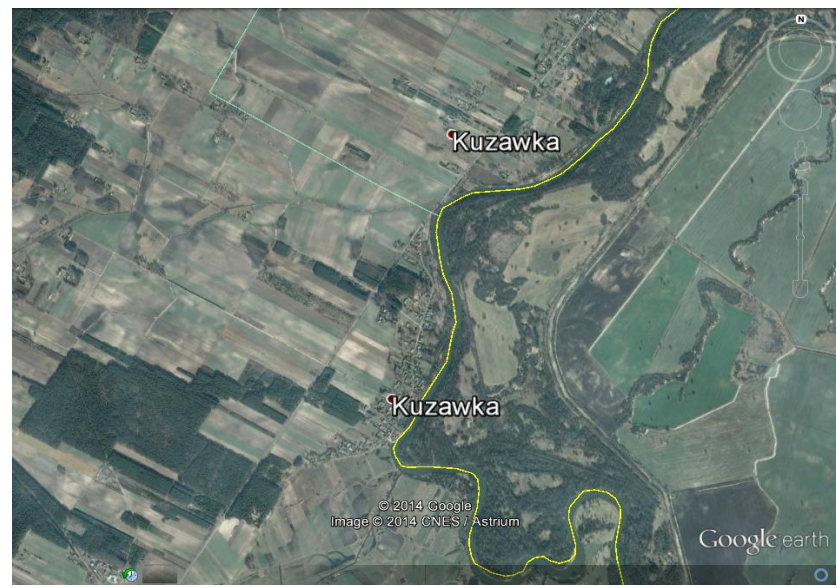

Fig. 3. Poland (left) - Belarus (right) boundary 
While that phenomenon now began to disappear, other differences can be seen in other parts of the world. The long boundary between USA and Mexico, which runs for about 3,400 km, partly along the Rio Grande River and partly in mainly desert area, can show how different political and economical regimes, deal with the same geographical area, divided by artificial boundary line (Fig. 1-2).

The same held truth refers to the Poland-Belarus boundary along the Bug River. The river, which never presented different geographical landscapes between both sides of it, now presents two different landscapes as the boundary between two countries was established in it (Fig. 3). While the state of Israel tried to protect its arboreal landscape and even to plant more trees Lebanon did not have such a policy and the local population exploited the trees for their use, a different landscape was developed along the boundary line established between these two states. There are lots of views like this all over the globe, but in this article the boundary between Israel and Egypt will be discussed.

\section{Israel-Egypt boundary}

The formation of the present Egyptian-Israeli border took over a period of almost 110 years during which four wars were fought between Israel and Egypt themselves as well as two World Wars involving the colonial powers which formerly ruled Egypt and Israel-Palestine. The first stage in the formation of the Israeli-Egyptian boundary was comprehensively dominated by imperial rivalry, mainly between the Ottoman Empire and the British Empire pushing to expand its influence in the Middle East.

The first map to indicate the location of the Egypt-Palestine border appeared in 1841 in the Sultan's Firman (Royal decree of the Ottoman Sultan) which delineated the boundaries of the area under Muhammad Ali's (Egyptian) rule. The map showed that the boundary between Egypt on one hand and Hejaz and Palestine on the other ran from Suez to Rafah (Biger 1978). It also showed that the Sinai Peninsula remained under Hejaz (Turkish) administration.

On the map, the Sinai boundary ran along a line from Suez to a point on the Mediterranean shore, between today's Rafah and Khan Yunis, both later attached to Palestine. It thus allocated the northwest area of Sinai Peninsula to Egypt sector (Hurewitz 1989, p. XII). The same Firman, authorized the ruler of Egypt to act in the Sinai Peninsula even beyond the above border line to safeguard the passage of Moslem pilgrims to Mecca (Brawer 1988, p. 61).

It became apparent after Britain gained control of Egypt and the Suez Canal (in 1882) that the 1841 border line crossed the southern tip of the Suez Canal so that 3-4 km of its southern entrance was located within the Turkish territory of Sinai. This fact together with international developments caused Lord Cromer, at 
that time British ruler of Egypt, to try to establish a new border in Sinai which would put Turkish forces at a greater distance from the Suez Canal.

The Ottoman rejected this demand, claiming that Egypt was an integral part of the Ottoman Empire and that there was, therefore, no need for a formal boundary such as a boundary which separates two sovereign states. The British used diplomatic as well as military pressure on the Ottoman Empire and this led to negotiations which produced an agreement which delimitated an administrative line between the Ottoman provinces of Hejaz and Jerusalem on one side and the Egyptian Sinai Peninsula on the other side (Warburg 1979, p. 681). The Turco-Egyptian boundary agreement was accordingly signed at Rafah on 1 October 1906.

The final demarcation of the Egypt-Palestine border took place during the summer months of June to October of 1906 with the British surveyors suffering from the heat and water and food shortage and wishing only to complete their job as fast as possible. The difficulties posed by the inaccessible topography which caused a change in the final location of the demarcated line of some areas - a deviation of 500 meters east from the proper border line (Brawer 1988, p. 69). During the final stage of the demarcation process telegraph poles were located at a distance of $1-2.5 \mathrm{~km}$ apart so that they would be inter-visible.

Later on the telegraph poles were replaced by stone markers, 1.5 meters high (Brawer 1988, p. 73). Some years later, in 1915, during the First World War, a map was produced by the Egyptian Survey office, showing for the first time the boundary line (Fig. 4).

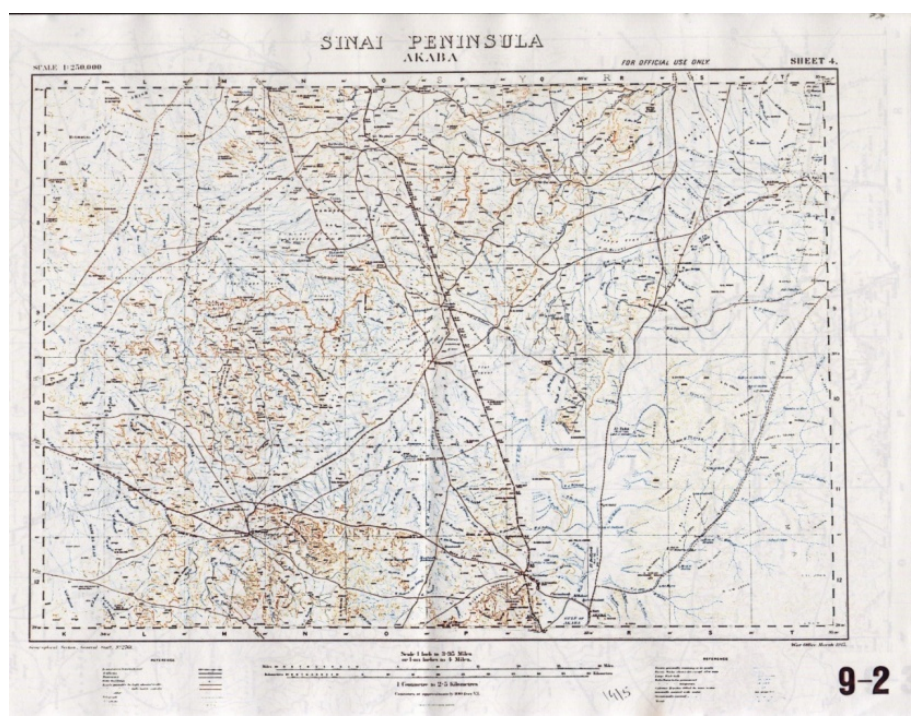

Fig. 4. Egypt (left) - Palestine (right) boundary 1915 
The Rafah-Taba line remained a border until the establishment of the State of Israel. In May 1948, following Israel's declaration of independence, the armies of its Arab neighbors, including Egypt, attacked Israel, and reached a point half way between the border and Tel Aviv.

Towards the end of the war, in March 1949, Israeli forces captured the southern area of Palestine, except for the Gaza Strip, up to the Gulf of Aqaba. The Israelis' pursuit of the Egyptian forces brought them into Sinai, and they captured a vast region between El-Arish and Nitzana (Cohen 1970, p. 401-402 Lorch 1976, p. 75). Israel had to withdraw all its forces from Sinai by 2 January 1949 and in the Armistice Agreement of 24 February 1949, Egypt acknowledged Israel's possession of the entire southern Palestine (the Negev) with the Auja-al Hafir (Nitzana) area being demilitarized and made into a headquarters of the mixed armistice commission.

Whereas the United Nations partition plan had allotted Israel an area of $15,850 \mathrm{sq} \mathrm{km}$, (over 9,500 sq km of this in the Negev) by the end of the 19481949 Israeli War of Independence, Israel held an area of 20,770 sq km, with the Negev comprising two-thirds of the area of the state. The armistice boundary line between Israel and Egypt coincided exactly with the Egypt-Palestine international boundary as demarcated in 1906, with the exception of the Gaza Strip.

The boundary deviated from the original 1906 boundary in order to leave the Gaza Strip under Egyptian rule - a situation which was based on the military positions held by both sides at the time of the ceasefire (Brawer 1988, p. 129130). The armistice line was de facto demarcated by the common EgyptianIsraeli military commission. The Gaza boundary passed along a line nearly parallel to the main communication artery - the Gaza-Rafah road, and was located on small sand hills 100 meters high. On the Israeli side of the border along the Gaza strip, a fence was constructed. As a result of it many Gaza residents were cut off from their grazing and agricultural lands which remained in Israel. The Bedouin population of the Israeli side of the border zone either moved to Egypt or eastward, to the Beer-Sheba region.

In 1967 Egypt demanded the UN evacuate its peace-keeping forces from Sinai and announced the closing of the Straits of Tiran and the Gulf of Aqaba to Israeli shipping. This resulted in the Six Day War between Israel and its surrounding Arab states (Egypt, Jordan, Syria), which lasted from 5-10 June 1967, led to an Israeli occupation of Egyptian Sinai, the Jordanian West Bank including East Jerusalem, and the Syrian Golan Heights.

The visit of the Egyptian president Anwar Sadat to Israel in 1977 was a major breakthrough in the Jewish-Arab conflict and the 1978 Camp David Accords set the framework for peace between Egypt and Israel. The Accords outlined 
provisions for full Israeli withdrawal from Sinai, the level of Egyptian force deployments there after withdrawal, and the right of free passage for Israeli ships through the Suez Canal. It also specified that full normal relations were to be established between the states. The Peace Treaty between Israel and Egypt was signed on 26 March 1979. By January 1980, Israel had withdrawn from twothirds of the Sinai Peninsula, and the final eastern part of Sinai was returned to Egypt in April 1982 (Akehurst 1981).

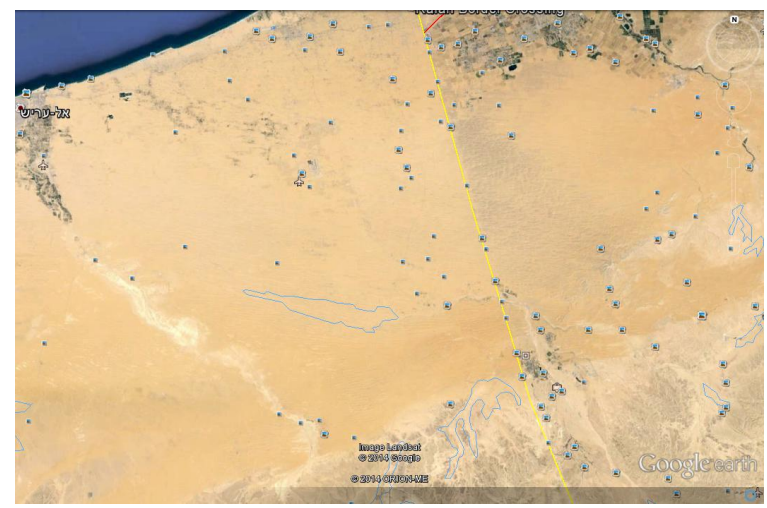

Fig. 5. Israel (right) - Egypt (left) boundary 2013

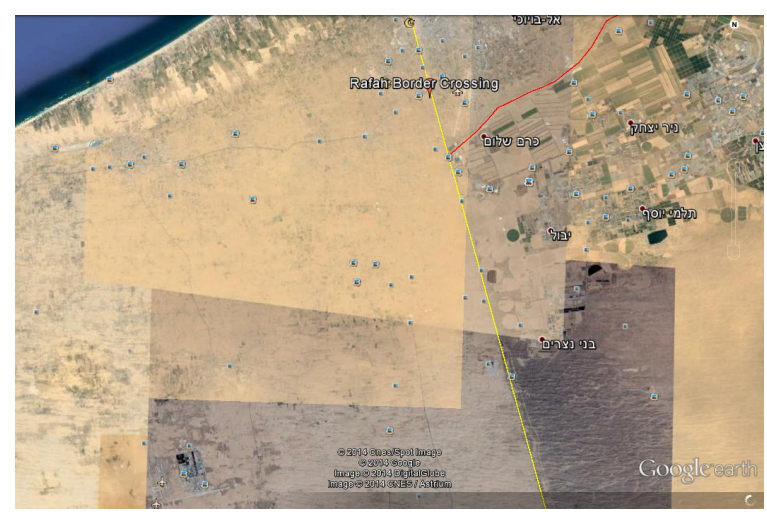

Fig. 6. Egypt (left) - Gaza (up) - Israel (right) boundary 2013

During the first 40 years of the boundary existence (1906-1949), there were not many changes in the landscape on both sides of the border. After 1949, as this line was accepted as the actual border between Israel and Egypt, Israel, for security reasons, close the area near the border to civilians. By this, the Bedouin tribes, which graze their flocks in that area, so that the natural vegetation can continue to exist, even in this very dry area. The Bedouins form the Egyptian side continue their grazing practice, by this cutting all the natural vegetation, 
make the area covered only with stones and sand. The difference can be seen from the air (Fig. 5-6). Moreover, the Israelis tried to establish some agriculture villages along the line, while the Egyptian side was not settled, as can be seen (Fig. 7-8).

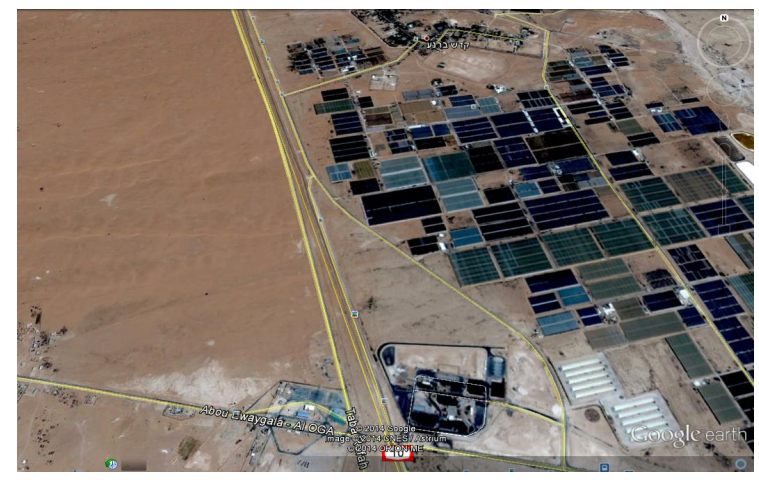

Fig. 7. Israel (right) - Egypt (left) desert boundary

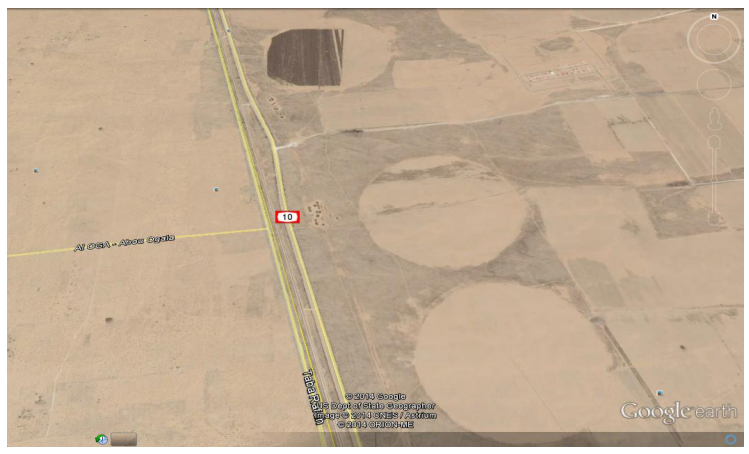

Fig. 8. Different Land use - Israel (right) - Egypt (left) boundary

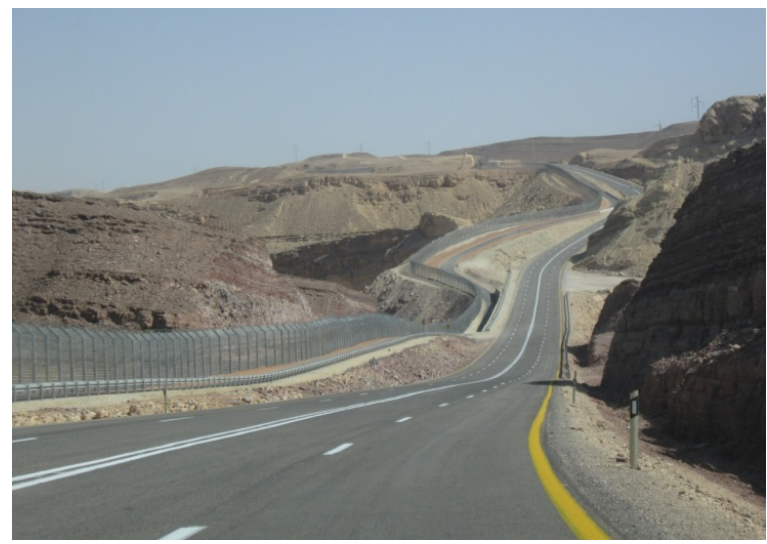

Fig. 9. Israel (right) - Egypt (left) boundary with an Israeli defense Fence 


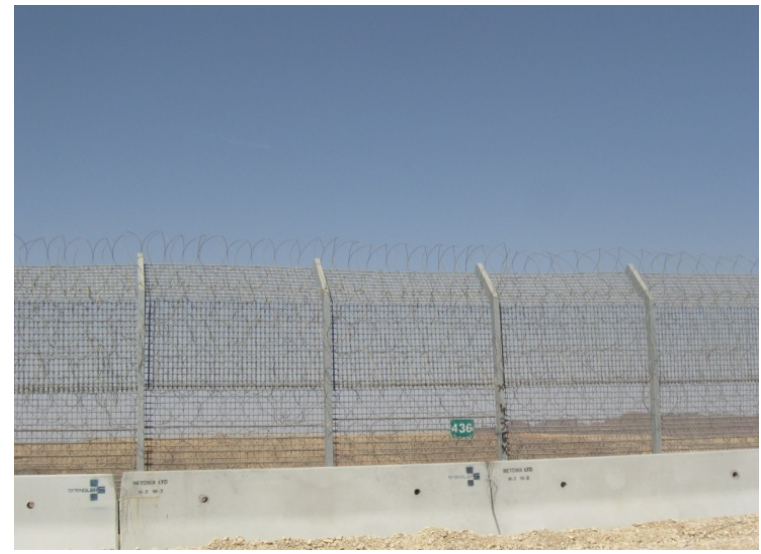

Fig. 10. The Israeli defense Fence - Israel-Egypt boundary

After the Peace Agreement, both countries built boundary roads, parallel to the boundary line, in the distance of about $100 \mathrm{~m}$ from each other. Both run in a desert area, and are used only by army vehicles. Israel built a high fence along the boundary, in order to prevent illegal crossing of the line (Fig. 9). It is about $7 \mathrm{~m}$. high, with barbered wire on and in it (Fig. 10). Egypt established some army post along the line in order to prevent such a crossing. Thus, in a totally desert, unpopulated area, two different landscapes were evolved.

\section{Conclusions}

Boundary lines are usually established along physical or man-made cultural lines. Even though, the delimitation of a boundary line, can change the identical geographical landscape which existed before the boundary line was established. It happens mainly when there are different economic as well as political ideological systems on different sides of the line. Rich side will be different from a poor side; natural reservation policy will create different landscape than an area of a non-natural protecting country. Changes of landscapes also depend on the relation between the two political systems, as peaceful relation will not bring more different landscape while hostile relations will create many more differences.

\section{References}

Akehurst M., 1981, The peace treaty between Egypt and Israel, „International Relations”, 7 (1), pp. 1035-1052.

Biger G., 1978, The first map of modern Egypt: Mohammed Ali's Firman and the map of 1841, „Middle Eastern Studies”, 14, pp. 324-352. 
Biger G., 1995, The encyclopedia of international boundaries, facts on files, New York.

Brawer M., 1988, The boundaries of Eretz Israel, Tel Aviv.

Cohen A., 1970, Israel and the Arab world, London.

Curzon of Keddleston, Lord, 1907, Frontiers, the Romanes lecture, Oxford.

Hurewitz J.C., 1989, Introduction, [in:] Toye P. (ed.), Palestine boundaries1833-1947, Vol. 1: Palestine-Egypt, London, pp. 10-33.

Kliot N., 1995, The evolution of Egyptian-Israeli boundaries. From colonial foundation to peaceful border, Boundary and Territory Briefing, 1 (8), Durham.

Lorch N., 1976, One long war, Jerusalem.

Muir R., 1975, Modern political geography, London.

Prescott J.R.V., 1978, Boundaries and frontiers, London.

Roberts P., 2001, La Gran Linea. Mapping the United States - Mexico boundary 19491857, Austin.

Schofield C. et al. (eds.), 2002, The Razor's Edge. International boundaries and political geography, London.

Warburg R., 1979, The Sinai peninsula borders, 1906-47, „Journal of Contemporary History”, 14, pp. 677-692.

\section{Granice międzynarodowe i ich wplyw na krajobraz Granica Izrael-Egipt jako studium przypadku}

\section{Streszczenie}

Granice międzynarodowe, ich historia, położenie, spory dotyczące ich dokładnego wytyczenia, ich strategiczne znaczenie i inne fakty są tematem zainteresowań wielu badaczy. Należą do nich prawnicy międzynarodowi, geografowie, historycy, politolodzy, badacze stosunków międzynarodowych, kartografowie, wojskowi. Zajmują się oni problemami granicy w różnych aspektach: jej położenia, statusu prawnego, historii, znaczenia w obronności kraju itd. Jednakże wpływ granic międzynarodowych na kształtowanie się krajobrazu nie znalazł większego zainteresowania wśród badaczy. W artykule przedstawiono kilka przykładów wyznaczenia granicy politycznej, które przyniosło zmiany krajobrazu po obu jej stronach. Jako studium przypadku omówiono granicę między Izraelem i Egiptem.

Słowa kluczowe: granice międzynarodowe, naturalny krajobraz, systemy polityczne, zmiana krajobrazu.

Gideon Biger, prof.

Department of Geography and Human Environment, Tel Aviv University, P.O.B 39040, Ramat Aviv, Tel Aviv 69978, Israel 